\title{
METODE PENGAJARAN VEDA PADAANAK USIA DINI
}

\author{
Oleh \\ Ni Kadek Surpi A \\ (Dosen Fakultas Brahma Widya IHDN Denpasar \\ Pimpinan Gerakan Bhagavad Gita Indonesia)
}

\begin{abstract}
In Hinduism, education begins in the Mother's womb. However, in relation to CaturAsrama (four stages of human life), education begins at the age of 0-25 years to be able to move to the next level. Vedic education can be done in early childhood as the general definition that children aged 0 years to 6 years. In principle, Vedic teaching can be done at any age, but with different methods. A number of popular methods have been practiced in Vedic teaching since ancient times such as Katha, Gatha, Narasamsi, Mantra, repetition, roleplaying and various other methods that can be adapted to local conditions. However, the Vedas are loaded with the teachings of wisdom, truth, and courage must be taught from an early age and further strengthened as adolescence and adulthood. Vedic teaching involves a holistic teaching system that builds people from within and enhances intellectual, emotional as well as spiritual intelligence to build superior and divine human beings as the Vedic ideals.
\end{abstract}

\section{Keywords : Veda, Sisya, Early Childhood, Gatha}

\begin{abstract}
Abstrak
Dalam ajaran Hindu, pendidikan dimulai sejak dalam kandungan. Akan tetapi kaitannya dengan Catur Asrama (empat tahapan hidup manusia), pendidikan dimulai pada usia 0-25 tahun untuk dapat melangkah ke jenjang berikutnya. Pendidikan Veda sudah dapat dilakukan pada anak usia dini sebagaimana definisi secara umum bahwa anak usia dini berusia 0 tahun sampai 6 tahun. Secara prinsip, pengajaran Veda dapat dilakukan pada segala usia, namun dengan metode yang berbeda. Sejumlah metode populer dilakukan dalam pengajaran Veda sejak jaman lampau seperti Katha, Gatha, Narasamsi, Mantra, pengulangan, bermain peran dan berbagai metode lainnya yang dapat disesuaikan dengan kondisi lokal. Namun demikian, Veda yang sarat dengan ajaran kebijaksanaan, kebenaran, keberanian harus diajarkan sejak dini dan selanjutnya diperkuat ketika masa remaja dan dewasa. Pengajaran Veda menyangkut sistem pengajaran yang holistik yang membangun manusia dari dalam serta meningkatkan kecerdasan intelektual, emosional maupun spiritual guna membangun manusia unggul dan berkarakter dewata sebagaimana cita-cita Veda.
\end{abstract}

Kata Kunci : Veda, Sisya, Anak Usia Dini, Gatha

I . PENDAHULUAN

Pendidikan merupakan hal yang sangat penting dalam peradaban Sanatana
Dharma. Sebab pendidikan menjadi kunci penting dalam pembangunan manusia menjadi manusia beradab, 
bersifat dewata (Manava). Dalam tradisi Hindu, pendidikan telah berlangsung sejak dalam kandungan dan dilanjutkan dengan pendidikan di dalam keluarga dan gurukula sebagai pendidikan formal. Mengingat pentingnya pendidikan, dalam sejarah peradaban Veda, tercatat universitas tertua di dunia merupakan universitas Veda yang telah berusia sangat tua yakni secara umum dikenal abad 6 SM yakni Takshasila (Taxila). Bahkan Apte (1949:8) menyebut universitas ini berdiri antara $1.000 \mathrm{BC}$ sampai $500 \mathrm{AD}$. Penelitian sejumlah ahli menunjukkan, universitas ini menggunakan kurikulum yang sangat komprehensif, mempelajari berbagai cabang ilmu pengetahuan dan pengajarnya merupakan guru besar, mereka yang ahli dibidangnya.

Pendidikan Hindu juga menekankan pentingnya anak usia dini. Namun di masa lampau, pendidikan anak usia dini lebih ditekankan pada pendidikan informal, kecuali untuk sejumlah wilayah khusus di Bharatavarsa. Namun demikian sangat disadari bahwa pendidikan anak usia dini sangat vital olehnya harus dilakukan secara sungguh-sungguh sebelum memasuki pendidikan formal dalam gurukula. Pengajaran Veda sudah dilakukan bahkan sejak anak di dalam kandungan ibu, namun dengan metode yang berbeda. Anak usia 0-8 tahun harus diajarkan berbagai kebijaksanaan dengan cara yang sangat menyenangkan.

Dalam undang-undang tentang sistem pendidikan nasional dinyatakan bahwa pendidikan anak usia dini adalah suatu upaya pembinaan yang ditujukan kepada anak sejak lahir sampai dengan usia enam tahun yang dilakukan melalui pemberian rangsangan pendidikan untuk membantu pertumbuhan dan perkembangan jasmani dan rohani agar anak memiliki kesiapan dalam memasuki pendidikan lebih lanjut (UU Nomor 20 Tahun 2003 Bab I Pasal 1 Ayat 14).

Konsep keilmuan PAUD bersifat isomorfis, artinya kerangka keilmuan PAUD dibangun dari interdisiplin ilmu yang merupakan gabungan dari beberapa displin ilmu, diantaranya: psikologi, fisiologi, sosiologi, ilmu pendidikan anak, antropologi, humaniora, kesehatan, dan gizi serta neuro sains atau ilmu tentang perkembangan otak manusia (Sujiono, 2009: 10). Sebelum perumusan ini, Veda sudah menerapkan sistem pengajaran Hindu yang sangat komprehensif untuk anak usia dini yang disesuaikan dengan kebutuhan anak di jamannya. Lebih jauh lagi dalam konsep Hindu, anak usia dini harus dijaga kemurnian dan kesuciannya, diajarkan cara berbahasa yang baik dan menyenangkan sehingga terbangun karakter mental yang baik.

\section{PEMBAHASAN}

\subsection{Pola Pendikan dalam Agama Hindu}

Metodeologi pengajaran dalam agama Hindu mencakup dalam tatanan kemasyarakatan dan tatanan rohani. Dalam konsep Hindu, tatanan kehidupan dikenal sebagai varnāśrama dharma. Varnāśrama merupakan sistem sosial Veda berupa empat tatanan sosial dan empat tatanan spiritual. Sistem sosial Veda ini bertujuan menjamin kesejahteraan masyarakat dan tercapainya tujuan tertinggi kehidupan manusia. Sistem sosial Veda ini semestinya harus ditegakkan demi pencapaian agung kehidupan manusia dan keteraturan semesta. Akan 
tetapi yang terjadi dewasa ini adalah tidak tegaknya varnāśrama dharma, sehingga menimbulkan kekacauan, berbagai persoalan dan Dharma, seolah tidak lagi ditegakkan. Konsep sosial ini sesungguhnya merupakan konsep sentral dan sangat penting dalam Kitab Suci Veda yang merupakan literatur paling kuno di muka bumi ini dan sekaligus kitab suci bagi penganut sanātana dharma.

Kitab-kitab purana mengajarkan tentang Varnasrama Dharma, dikarakterisasi oleh kewajiban dari empat golongan masyarakat dan tingkatan dalam hidup ini. Empat varna yang dimaksud adalah, Brāhmana, Ksatriya, Vaiśya dan Śūdra. Catur asrama yakni Brahmacāri, grhastha, vanaprasta dan sanyasi.

Kelompok pertama dalam Catur Varṇa adalah Brāhmana. Kurma Purana menjelaskan bahwa kaum Brāhmana adalah golongan pertama dalam empat golongan yang ada. Brahma menciptakan sembilan putra dari kekuatan pikirannya. Nama-nama putraituadalah Marīci, Bhrgu, Angira, Pulastya, Pulaha, Kratu, Daksa, Atri dan Vasiștha. Putra-putra ini menjadi rsi dan mereka adalah Brāhmana pertama. Mereka diciptakan dari mulut Brahma (Debroy dan Debroy, 2002 : 6). Ada enam hal yang harus dilakukan oleh seorang Brāhmana, yaitu yajña (melakukan korban suci), yajana (bertindak sebagai pendeta dalam upacara korban), dāna (melakukan amal), pratigraha (menerima amal), adhyāpana (memberikan pengajaran) dan adhyayana (belajar). Seorang Brāhmana yang melakukan ini dengan baik ia akan mencapai tempat yang dikenal sebagai prajāpatya, nama lain dari kediaman Brahma, yakni Brahmaloka (Debroy dan Debroy, 2001 : 7). Agni Purana (Sanjaya,
2001 : 46) menegaskan melakukan upacaa kurban, menyumbang kepada mereka yang membutuhkan, dan mempelajari kitab suci adalah tugas para Brāhmana, Ksatriya dan Vaiśya, dan sebagai tambahannya para Ksatriya hendaknya melindungi kebaikan dan membasmi kejahatan. Para vaiśya hendaknya melakukan kegiatan perdagangan, bertani dan beternak. Sedangkan kewajiban para śūdra adalah melayani ketiga varṇa diatasnya. Jika seorang Brāhmana melakukan upacara upavita, yaitu pengikatan benang suci, maka mereka dinyatakan telah mendapatkan kelahiran kedua secara spiritual (dvijati).

Brāhmana atau cendekiawan-para pemikir, pendidik, guru pengajar, ahli kitab atau ritus, pendeta dan sebagainya. Profesi mereka sesuai dengan potensi diri mereka, yaitu mendidik anak bangsa; mengarahkan masyarakat; menasehati pemerintah dan sebagainya (Krishna, 2004 : 175). Brāhmana dikenal sebagai golongan cerdas dalam masyarakat. Lahir dengan sifat alamnya yakni belajar, mengkaji, berpikir dan mengajar di masyarakat. Dalam tradisi Veda, Brāhmana adalah mereka yang secara alami tertarik dengan pengajaran Veda. Bukan belajar karena menginginkan jabatan atau pekerjaan tertentu, melainkan sifat dasar atau sifat alami (svabhāva). Mereka secara sukarela melestarikan tradisi Veda, belajar dan mengkaji Veda dengan kesungguhan hati dan mengabdikan diri kepada masyarakat melalui pengajaran Veda.

Ksatriya merupakan golongan kedua dalam konsep catur varna. Kurma Purana menyebutkan mereka diciptakan dari tangan Brahma. Tugas dari ksatriya adalah dāna (melakukan amal), 
adhyayana (belajar) dan melakukan yajña (pengorbanan). Tetapi tugas utama mereka adalah menghukum orang-orang jahat dan melindungi orang-orang baik. Seorang ksatriya yang melakukan tugas ini dengan baik maka ia akan mencapai tempat kediaman Indra yaitu Indraloka (Debroy dan Debroy, 2002 : 7). Dalam tatanan sosial, ksatriya merupakan golongan yang bekerja melalui kekuatan. Dalam mantra purușa sūkta, ksatriya disimbolkan dengan bahu/tangan, karena pada bahu terdapat kekuatan. Siapa saja yang bekerja dengan kekuatan untuk melindungi atau kesejahteraan negara disebut sebagai ksatriya

Vaiśya adalah golongan ketiga dari empat golongan yang ada. Mereka tercipta dari paha Brahma. Seperti para ksatriya, vaiśya juga melakukan amal, belajar dan melakukan korban suci. Tetapi tugas utama mereka adalah pertanian. Seorang vaiśya yang melakukan tugas ini dengan baik akan hidup dengan dewa angin Vayu (Debroy dan Debroy, 2001 : 7). Dalam purana yang lain perdagangan dan peternakan digolongkan dalam pertanian. Visnu Purana menegaskan tugas vaiśya adalah memelihara ternak, bidang perdagangan dan pertanian. Sebagai tambahan vaiśya juga harus mempelajari kitab suci, memberikan sedekah dan melakukan upacara korban (Sanjaya, 2001: 40). Śúdra adalah golongan terakhir dari keempat golongan yang ada. Mereka tercipta dari kaki Brahma. Tugas utama mereka adalah melayani ketiga golongan lainnya. Seorang śúdra dapat menjadi buruh sebagai mata pencaharian mereka. Seorang śūdra yang dapat melakukan tugas ini dengan baik maka ia akan hidup dengan para gandharva (penyanyi surgawi) (Debroy dan Debroy, 2002: 8). Karena śüdra berkewajiban mencari nafkah dengan melayani tiga varṇa lainnya, ia juga diperkenankan berdagang atau menjadi pengrajin (Sanjaya, 2001:40).

Dalam tatanan spiritual, Catur Asrama, brahmacāri, merupakan tahap kehidupan yang pertama. Brahmacarya dapat diartikan selibat, pembujangan, mencari ilmu pengetahuan atau masa belajar (Debroy dan Debroy, 2002:8; Sanjaya, 2001:40). Kitab-kitab purana menjelaskan, tahap pertama ini merupakan tahap yang sangat penting bagi manusia demi kebaikan hidup dan perjalanan spiritualnya. Visnu Purana menjelaskan, setelah seseorang ditasbihkan dengan benang suci maka ia harus dikirim ke pertapaan seorang guru untuk mempelajari kitab Veda. Setiap pagi dan sore ia akan melakukan pemujaan pada Surya dan Agni serta bersujud pada gurunya. Setelah doa selesai, siswa hanya akan duduk setelah gurunya. Ia tidak akan pernah menentang gurunya. Apapun nasehat gurunya akan dilakukannya. Setiap pagi murid akan bangun lebih awal dari gurunya, mengambil air dan bunga untuk gurunya. Murid akan mempelajari berbagai cabang dari Veda, berbagai pengetahuan dan pengetahuan ketuhanan. Pada akhir masa belajarnya, seorang murid wajib membayar daksina (balas jasa) pada gurunya dan meminta ijin untuk kembali ke masyarakat menempuh hidup sebagai grhastha (Sanjaya, 2001 : 40-41). Dalam Visnu Purana ini dijelaskan, ketika seorang anak telah mendapatkan upacara upanayana, ia akan dikirim ke pertapaan seorang guru, guna mempelajari berbagai cabang dari Veda dan pengetahuan yang 
sangat penting dalam hidupnya. Ia harus melakukan pemujaan secara tekun serta mematuhi perintah guru. Kurma Purana menjelaskan tugas utama dari seorang yang berada dalam tahap ini adalah belajar Veda dan melayani guru (pengajar) dengan baik (Debroy dan Debroy, 2002:8).

Dalam bangunan kehidupan, tahap ini merupakan tahap pembentukan landasan atau fondasi kehidupan sehingga seluruh tahap bangunan kehidupan akan menjadi kokoh dan indah, manakala tahap ini dijalani dengan sempurna. Brahmacāri sesungguhnya bukan hanya sekedar masa menuntun ilmu, melainkan sebuah masa yang sangat penting keagungan hidup. Veda menyatakan Brahmacāri harus mampu mengendalikan dirinya dari dorongan nafsu seks guna memiliki kekuatan suci cahaya kedewataan (Titib, 1996 : 392).

Swami (2012 : xii) menyatakan mengingat pentingnya kehidupan sebagai Brahmacāri, hal ini seharusnya tidak boleh diabaikan. Brahmacāri merupakan dasar dari keempat asrama dan harus dilaksanakan oleh setiap laki-laki dan wanita secara serius dan tulus hati agar mencapai tujuan yang nyata dan jalan kembali kepada Tuhan. Dalam Srimad Bhagavatam 1.1.10 dikatakan " Tidak mungkin mengendalikan pikiran dan indria-indria, tanpa mengikuti prinsipprinsip Brahmacāri. Guru-guru spiritual menegaskan, kegagalan tiga asrama berikutnya karena tidak terpeliharanya institusi Brahmacāri dan tidak banyak guru-guru yang mengajarkan prinsipprinsip Brahmacāri, sehingga karakter kokoh dharma tidak terbangun di masa yang sangat penting ini.
Brahmacāri lahir dari hati wujud semesta Tuhan (Bhagavata Purana 11.17.14), maka Brahmacāri merupakan pijakan pertama dalam kehidupan manusia untuk mensucikan hati agar seseorang memiliki sifat-sifat kedewataan (daivi sampad) dibawah bimbingan guru kerohanian.

Tahap brahmacāri ini khususnya bertujuan untuk berlatih, melatih diri dalam hal mengendalikan indria dan menundukkan pikiran, berlatih untuk nantinya menjadi ghastha, vānaprastha, sannyāsi (Vikasa Swami, 2012 : 3).

àyus tejo balam vīryam prajña śrīś ca yaśas tathā punyatā satpriyatvam ca vardhate brahmacaryay $\bar{a}$

"Dengan menjalani kehidupan brahmacāri, umur panjang, cahaya tubuh, kekuatan diri, vitalitas, pengetahuan, kecantikan, kemasyuran, keberuntungan dan kesetiaan serta kebenaran akan semakin meningkat. "

\section{Srimad Bhagavatam $\quad 6.1 .12$} menjelaskan ada delapan aspek yang harus dihindari oleh seorang Brahmacāri, yakni ;
smaranan kīrtanam kelim preknanan guhyabhamanam samkalpo dhyavasāyaś ca kriyā-nirvmttir eva ca

Seseorang seharusnya tidak :

1. Berpikir tentang wanita

2. Berbicara tentang kehidupan seks

3. Bermesraan dengan wanita 
4. Memandang wanita dengan penuh nafsu

5. Berbicara secara intim dengan seorang wanita

6. Memutuskan untuk melakukan hubungan seksual

7. Berusaha mengejar kehidupan seks

8. Sibuk dalam kehidupan seks

Dalam kehidupan modern, delapan aspek seorang Brahmacāri ini dilanggar dan tidak menjadi perhatian bagi mereka yang sedang menuntut ilmu atau pada masa Brahmacāri. Inilah awal kehancuran tatanan manusia dimana tugas dan kewajibannya tidak mendapat perhatian.

Agni Purana (Sanjaya, 2001: 47) menegaskan tugas dan kewajiban seorang Brahmacāri, yakni tidak boleh minum minuman yang memabukkan, makan daging serta mengumbar hawa nafsu. Hendaknya ia meninggalkan segala bentuk kekerasan dan pikiran tentang wanita. Kewajiban utamanya adalah mempelajari dan mendiskusikan kitab suci Veda dan bergaul dengan para sarjana Veda. Selain itu ia juga harus melakukan disiplin spiritual baik meditasi, japa, yoga dan sebagainya.

Puluhan purana menjelaskan tugas dan kewajiban seorang Brahmacāri yang merupakan landasan pertama kehidupan manusia. Dapat disimpulkan adalah seorang Brahmacāri harus melakukan tapa dalam tiga aspek, yakni pikiran (tapa bhatin), tapa mulut dan tapa perbuatan. Tapa pikiran yang dimaksud adalah mendisiplinkan diri untuk fokus pada pembelajaran, tanpa terganggu dengan kecenderungan kesenangan, seperti memikirkan lawan jenis atau hal-hal yang berhubungan dengan sensual. Bhatin seorang sisya harus senantiasa bersih agar mampu menyerap pembelajaran dengan baik. Tapa mulut yang dimaksud adalah dalam hal makan dan berbicara. Ditegaskan Brahmacāri tidak boleh minum minuman keras atau minuman yang memabukkan, tidak boleh makan daging dan senantiasa menjaga ucapannya agar tidak menyimpang. Sisya tidak boleh memaki atau mengucapkan katakata kasar, apalagi kepada gurunya. Tapa perbuatan yang dimaksud adalah ia harus menjaga agar badannya hanya digunakan untuk hal-hal yang berbau rohani dan kebajikan semata. Kegiatan harian seorang Brahmacāri adalah bangun pagi-pagi, melakukan pemujaan dan mempelajari susastra Veda.

Ada delapan cara belajar para sisya di jaman dulu (Machwe, 2000 : 165) yakni:

1. Shushrusha : melayani guru secara fisik

2. Shravanam: mendengarkan guru

3. Bahu-shruta : mendengar dengan baik

4. Grahanam : menerima hal-hal yang dikatakan oleh guru

5. Dharanam : mengingat hal-hal yang dikatakan oleh guru

6. Uhapoha : berdiskusi dan berdebat

7. Nijnana : membuat pengetahuan khusus, belakangan istilah ini menjadi ilmu pengetahuan

8. Tattvabhinivesha : pengetahuan yang telah diperolah agar diterapkan.

Veda juga menegaskan tentang keagungan selibat atau Brahmacāri, yang dapat dilaksanakan oleh semua varṇa.

brahmacaryena tapasā

rājā rantram vi rakśati

ācāryo brahmacaryena 
brahmacārinam icchate

Atharvaveda XI.5.17

"Seorang Raja, dengan sarana menjalankan Brahmacāri, bisa melindungi bangsanya.

Seorang acarya (guru, pembimbing), yang sedang melakukan Brahmacāri, berkeinginan mengajar siswa yang saleh." (Titib, 2006:393)

Mantra tersebut menjelaskan bahwa seorang raja yang menjalankan Brahmacāri mampu melindungi negaranya dengan kekuatan dari tapa Brahmacāri tersebut. Demikian pula para pendidik, acarya mampu mengajar dengan penuh potensi, mengajarkan kebajikan kepada siswanya dengan menerapkan konsep Brahmacāri. Hal ini tidaklah salah sebab Veda menjelaskan kekuatan Brahmacāri yang dikatakan mampu menopang bumi dan langit, sebagaimana mantra berikut.

sa dādhāra pmthivim divam ca

Atharvaveda XI.5.1

\section{"Seorang Brahmacāri}

menopang bumi dan langit"

Dikatakan seorang Brahmacāri mampu menopang bumi dan langit oleh karena kekuatan yang dimiliki dari tapa yang dilakukan secara sungguh-sungguh. Tapa seorang Brahmacāri akan mampu menimbulkan kekuatan yang sangat besar. Lebih jauh Atharvaveda XI.5.1 menyatakan "tasmin devam sammanaso bhavanti- semua Dewata berdiam di dalam diri seorang Brahmacāri." Oleh karena kekuatan dan kesuciannya, semua dewata berdiam diri pada seorang Brahmacāri. Brahmacāri merupakan penopang kehidupan manusia, olehnya semestinya dijalankan dengan kesungguhan guna membangun landasan kehidupan berikutnya. Sebab hanya seorang Brahmacāri yang baik yang akan mampu menjadi grhastha yang baik dan tahapan hidup selanjutnya.

Jika dihubungkan dengan umur manusia Kaliyuga, sejumlah penjelasan dari Susastra Hindu dan para Acarya, Catur Asrama dapat dikonstruksi sebagaimana gambar berikut.

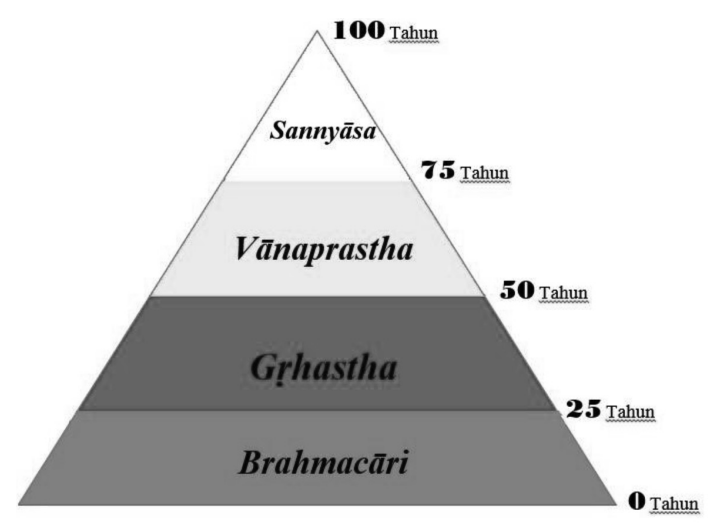

Gambar 1. Konstruksi Catur Asrama dikaitkan dengan umur manusia.

Melihat piramida Catur Asrama dikaitkan dengan umur manusia di Kaliyuga, maka pendidikan dimulai sejak usia 0 tahun dan idealnya hingga usia 25 tahun. Namun dalam peradaban Veda ada ketentuan klasik tentang pembelajaran Veda. Diperlukan waktu 12 tahun untuk menjadi ahli pada satu cabang Veda. Olehnya, pendidikan dapat berlangsung 12 tahun, 24 tahun, 36 dan 48 tahun dengan memperhatikan pembelajaran pada berbagai bidang ilmu. Lulusannya disebut Snataka dan upacara kelulusan disebut Samavartana. Jika dikonversi dalam pengetahuan modern, dapat 
diperoleh pandangan pendidikan setara Diploma, S1, S2 dan S3 terkait dengan penguasaan bidang ilmu.

Sumber kekacauan di muka bumi ini juga disebabkan tidak diterapkannya varn̄âśrama dharma. Seorang Brahmana yang semestinya mempelajari kitab suci Veda dan memberikan petunjuk pada Varna lainnya tampaknya lalai melaksanakan tugas. Bahkan dalam beberapa kasus, Brahmana mengumpulkan kekayaan yang berhubungan dengan tugas melakukan ritual agama. Brahmana mestinya mahir dalam pembelajaran Veda, mulai dari sastra-sastra agama, purana, itihasa, Bhagavad Gita, Smrti dan Veda Sruti. Sehingga ketika ada penyimpangan di masyarakat, peran Brahmana karena kesucian dan Brahma teja yang dimiliki mampu melakukan perbaikan dan menuntun masyarakat termasuk raja (pejabat pemerintahan). Sementara Ksatria menjamin Varna yang lain mampu melaksanakan tugasnya dengan keamanan Negara, kemakmuran dan perlindungan darikemungkinan serangan musuh. Adalah tugas seorang kesatria yang berhubungan dengan politik dan negaranya. Selain itu, ia juga harus mempelajari Kitab Suci dan sastra yang berhubungan dengan pemerintahan Negara, kepemimpinan dan kemakmuran. Sementara Vaisya bertanggung jawab masalah ekonomi dan kemakmuran. Dialah penggerak roda ekonomi, sementara Sudra mendukung Varna yang lain seperti menyediakan tenaga kerja yang baik dalam lapangan pekerjaan. Tatanan masyarakat akan hancur manakala para Brahmana melalaikan perintah Veda, mencari keuntungan dan tidak menjadi Sisya Veda. Para ksatria melakukan korupsi dan tidak bersedekah serta tidak melakukan doa. Para Vaisya mengacaukan ekonomi dengan manipulasi dan mereka yang tidak ahli Veda menjadi pemimpin atau peran dari Brahmana. Seorang pemimpin politik dan negara mestinya kaum ksatria atau mereka yang sejak muda tertarik dengan hal itu. Ia harus mempelajari Veda. Tetapi sekarang para pemegang kekuasaan banyak yang berasal dari 'jalanan,' suka mabuk-mabukan, peminum alkohol, tidak mengetahui Veda, tidak mempelajari Arthasastra, Canakya Niti Sastra tetapi terpilih dan menjadi pemimpin politik, dilantik menjadi anggota legeslatif bahkan bupati. Sehingga kita melihat kekacauan dimana-mana, dalam semua tingkatan dan tiada teladan di masyarakat. Sementara orang-orang baik, para cendekiawan tidak mendapat tempat di masyarakat.

Demikian pula dalam empat tahapan kehidupan (fase kehidupan manusia). Seorang Brahmacarya tugas utamanya adalah mempelajari Veda dan pengekangan diri. Ia sama sekali tidak boleh mengumbar hawa nafsu. Sementara dewasa ini, mulai dari tahapan hidup yang pertama sudah kacau. Para siswa terlibat dalam pertengkaran, tawuran bahkan aktivitas politik. Para Brahmacari tidak lagi menerapkan disiplin diri. Para pelajar tampak lumrah menyentuh wanita. Brahmacarya wanita melakukan aborsi atau hamil diluar nikah, tidak melakukan pembelajaran Veda. Juga tidak adanya disiplin diri untuk bangun pagi-pagi dan berdoa. Masa menuntut ilmu hanya diasumsikan dengan masa mencari ijazah untuk mendapat pekerjaan nanti. Tanpa adanya disiplin dan pembelajaran Veda. Para sisya yang mestinya mengendalikan diri (selibat) malah dianggap tidak tabu lagi 
melakukan hubungan seks dan dimanamana ketika pelajar berkumpul yang dibicarakan hanyalah perihal kehidupan bebas mereka, kosong spiritualitas dan kitab suci.

Tahapan hidup berikutnya yang juga tidak kalah sakralnya adalah grhasta. Grahasta sebagai mendukung kehidupan, bukan berumah tangga semata, melaksanakan yajna, agnihotra. Ia harus bersedekah secara teratur terhadap para Brahmana, para pertapa dan para Brahmacarya. Tahapan ini mestinya benar-benar mendukung asrama yang lain, bukan sekedar berumah tangga, mengumbar hawa nafsu dan menimbun kekayaan. Grhasta memiliki kewajiban suci untuk bersedekah dan melakukan yajna. Ia harus menjaga kehidupannya yang suci dengan tidak menyentuh orang lain yang bukan pasangannya. Dalam tradisi Vaishnava, hubungan seks hanya diperbolehkan untuk mendapatkan keturunan suputra.

Sementara tahapan berikut yakni Vanaprasta dan Sannyasa hampir-hampir ditinggalkan oleh masyarakat umum. Tidak jarang ada pemandangan, orang berumah tangga hingga ajal menjemput tanpa merubah pikirannya. Juga banyak yang mestinya telah memasuki Vanaprasta tetapi masih ingin memegang jabatan, terlibat dalam politik dan tata Negara atau tetap mengurus perekonomian. Bukan pemandangan yang aneh jika seorang nenek atau kakek berusia 80-an masih menjadi pemimpin perusahaan, menjadi hakim atau jabatan lainnya yang menghasilkan uang dan memegang kekuasaan. Mestinya, sesuai ajaran kitab-kitab purana, seseorang yang telah memiliki putra-putri dewasa, ia harus mulai meningkatkan spiritualitas. Melakukan tirtayatra, belajar kitab suci dan lebih intensif melakukan sadhana spiritual. Ia dapat meninggalkan istrinya dalam pengawasan putra-putrinya, mulai melakukan tapasya dan belajar Brahmavidya. Demikian juga sang istri harus mendapatkan tuntunan dari guruguru spiritual. Pada tahap ini mestinya sudah tidak melakukan hubungan seksual lagi, seolah kembali menjadi Brahmacari. Sekarang, tidak jelas lagi, saat mana seorang berada dalam tahap Grhasta dan Vanaprasta, sebab kebanyakan orang berumah tangga dan melakukan hubungan seksual hingga usia tua. Bahkan kakek nenek masih berselingkuh atau nikah lagi. Demikian pula tahapan terakhir Sannyasa tidak dijangkau oleh masyarakat umum.

Kekacauan Varnasrama Dharma dan Catur Asrama telah membuat tatanan dunia yang kacau, juga karma manusia semakin merosot. Masa kecil dibuai mimpi keindahan kehidupan seksual, masa grhasta tidak mendukung kehidupan yang lain, hanya sekedar berumah tangga tanpa mengetahui disiplin grhasta, melakukan hubungan seks, menikmati minuman keras dan tahapan berikutnya tidak direncanakan. Tidak melakukan agnihotra, tidak bersedekah dan tidak melakukan kewajiban sebagaimana mestinya. Ini tentu saja bukan perbaikan karma dalam kehidupan, melainkan menyia-nyiakan kehidupan suci sebagai manusia. Menyia-nyiakan kesempatan yang berikan atas kebaikan kebaikan karma masa lalu. Dengan demikian kehidupan manusia semakin merosot. 


\subsection{Metode Pengajaran Veda pada Anak Usia Dini}

Anak usia dini adalah anak yang baru dilahirkan sampai usia 6 tahun. Usia ini merupakan usia yang sangat menentukan dalam pembentukan karakter dan kepribadian anak (Sujiono, 2009: 7). Usia dini merupakan usia di mana anak mengalami pertumbuhan dan perkembangan yang pesat. Usia dini disebut sebagai usia emas (golden age). Pada usia emas inilah mestinya diajarkan berbagai ajaran moral dan penguatan karakter. Berdasarkan tinjauan secara psikologi dan ilmu pendidikan, masa usia dini merupkan masa peletak dasar atau fondasi awal bagi pertumbuhan dan perkembangan anak. Apa yang diterima anak pada masa usia dini, bahkan makanan, minuman, serta stimulasi dari lingkungannya memberikan kontribusi yang sangat besar pada pertumbuhan dan perkembangan anak pada masa itu dan berpengaruh besar pertumbuhan serta perkembangan selanjutnya. Pertumbuhan dan perkembangan anak tidak dapat dilepaskan kaitannya dengan perkembangan struktur otak. Dari segi empiris banyak penelitian yang menyimpulkan bahwa pendidikan anak usia dini sangat penting, karena pada waktu manusia dilahirkan, menurut Clark (dalam Sujono, 2009) bahwa kelengkapan organisasi otaknya mencapai $100-200$ milyard sel otak yang siap dikembangkan dan diaktualisasikan untuk mencapai tingkat perkembangan optimal, tetapi hasil penelitian menyatakan bahwa hanya $5 \%$ potensi otak yang terpakai karena kurangnya stimulasi yang berfungsi untuk mengoptimalkan fungsi otak. Dalam pendidikan Hindu, anak usia dini harus mendapatkan pendidikan (cenderung non-formal) baik dalam media pembelajaran keluarga, lingkungan ashram maupun pusat-pusat pendidikan yang dibangun. Upaya pembelajaran Veda disesuaikan dengan usia anak, yakni berusia dibawah delapan tahun. Berbagai metode pembelajaran biasanya digunakan secara umum untuk mengajarkan pengetahuan Veda, budaya dan karakter yang kuat, yakni :

\section{Cerita (Katha)/Story Telling}

Metode pembelajaran melalui cerita sangat terkenal dalam pendidikan Hindu baik di masa lampau maupun pendidikan Hindu modern. Cerita tertentu atau kutipan dari Itihasa disebut Akhyana. Cerita yang sangat terkenal dalam Purana (Bhagavata Purana) yakni Cerita Dhruva dan Prahlada. Keduanya memiliki tokoh sentral anak-anak yang menunjukkan karakter yang kuat serta keyakinan kepada Tuhan (Sri Visnu). Demikian pula dalam susastra Hindu bertebaran berbagai cerita yang dimaksudkan sebagai bentuk pembelajaran bagi umat manusia.

\section{Lagu}

Menyanyi merupakan aktivitas yang menyenangkan bagi anak. Sejak jaman lampau pengajaran Veda dan nilainilai kemanusiaan telah dilakukan lewat lagu. Jutaan lagu dan syair telah digubah oleh para Rsi, pengawi maupun penulis sejak jaman lampau. Lagu-lagu pemujaan telah digubah dalam berbagai bahasa yang berisikan tentang pemujaan Tuhan, kebenaran, moralitas maupun cinta kasih. Penterjemahan ajaran Veda melalui lagu telah dilakukan guna keperluan umat manusia pada segala usia. Pembelajaran melalui lagu justru mendesak pada anak 
usia dini, sebab jaman ini anak-anak telah terbiasa menyanyikan lagu orang dewasa yang penuh dengan romantika bahkan nilai-nilai yang tidak baik. Hal itu akan berpengaruh buruk pada anak-anak.

\section{Gatha (syair yang dikidungkan)}

Jika lagu dapat mengikuti berbagai aliran lagu dan music modern, Gatha dan Narasamsi merupakan seni yang lebih klasik. Dalam peradaban Sanatana Dharma, Rsi dan para Acarya telah menggubah syair. Potongan-potongan Mantra dan Sloka dijadikan sebagai inspirasi utama dalam menciptakan syair. Syair-syair ini dapat digubah dalam berbagai bahasa demi menyampaikan pembelajaran secara sederhana kepada masyarakat luas dalam berbagai usia.

\section{Narasamsi (Kidung Pujian) \\ Narasamsi atau kidung pujian} menjadi media pembelajaran yang menarik bagi anak usia dini terutama di jaman yang lebih tua. Kidung pujian atas kemenangan/Kejayaan Sri Rama misalnya dihafal oleh orang tua untuk dijadikan sebagai media pembelajaran. Demikian pula pujian kepada Sri Krishna sang Penggembala Sapi, Para Gopi (penggembala perempuan) telah menjadi media pembelajaran yang sangat baik bagi anak. Bukan hanya itu, sejumlah kidung digubah guna memuji kepribadian seorang anak, sebagaimana halnya ketika Krishna lahir, penduduk terutama kaum ibu berdatangan untuk menyanyi, memuji ketampanan Krishna Balita sebagai keripbadian yang bercahaya. Demikian pula ketika di dalam ayunan berbagai lagu dan syair dikumandangkan untuk memuji kepribadian yang lahir sebagai sebuah berkah bagi keluarga dan penduduk. Pujian sesungguhnya menjadi salah satu media pembelajaran seorang anak guna meningkatkan kepercayaan diri dan sangat dihargai.

\section{Mantra}

Sejumlah mantra sederhana dapat diajarkan pada anak usia dini, diantaranya mantra terkenal dari Pandawa Gita berikut;

Tvameva Mata Cha Pita

Tvameva

Tvameva Bandhuscha Sakha

Tvameva

Tvameva Vidya Dravinam

Tvameva

Tvameva Sarvam Mama

Deva Deva

"Oh Tuhan, Engkau adalah

Ibu ku, Engkau adalah ayah

ku, engkau adalah kerabatku

yang paling dekat, engkau

adalah sahabatku yang

terkasih. Engkau adalah

pengetahuan, Engkau adalah

kekayaan dan Engkau adalah

segala-galanya bagiku."

Mantram ini memberikan kekuatan kepada setiap orang, sekaligus mengajarkan bertabah hati ketika mengalami kemalangan, sebab Tuhan sendiri yang akan menjadi Ibu, Ayah, Kerabat, Sahabat, Pengetahuan dan Segalanya bagi kita.

Selain itu, anak-anak juga harus diajarkan mantra-mantra singkat untuk kehidupan seperti doa sebelum tidur, bangun tidur, mulai belajar, menyantap makanan, mantra mandi, sebelum bepergian dan sebagainya. Mantra ini 
akan membentuk kebiasaan baik pada diri seorang anak. Sama seperti pembelajaran Veda, pembelajaran mantra tidak mengenal batas usia. Bahkan sangat baik mengenalkan mantra lebih awal dari fase kehidupan manusia. Secara teori Catur Asrama, anak usia 0 tahun sudah dapat diajarkan mantra.

\section{Bermain peran}

Bermain peran merupakan hal yang sangat menyenankan bagi setiap anak. Guru yang baik akan membimbing siswanya untuk mendapatkan banyak pelajaran dari bermain peran. Berbagai drama singkat sangat terkenal untuk diperankan oleh anak usia dini. Berperan sebagai Prahlada, Dhruva atau Raja Puri menjadi media pembelajaran yang sangat baik. Demikian pula peran sebagai Arjuna, Sri Krishna, Abhimanyu menjadi nilai tersendiri. Namun jika harus memerankan drama secara lebih utuh terutama yang memiliki peran antagonis misalnya sebagai Sakuni, Duryodana, Raksasa guru harus menjelaskan bahwa peran tersebut tidak layak untuk diteladani karena akan menghancurkan diri sendiri maupun peradaban.

\section{Tanya Jawab (Question and Answer method).}

Cara ini efektif dilakukan mengingat anak usia dini memiliki keingintahuan yang sangat tinggi dan antusias terhadap banyak hal. Metode ini sangat efektif untuk menjelaskan topic tertentu, misalnya penghormatan terhadap sapi dalam budaya Sanatana Dharma, Sejarah Veda, pengetahuan ketuhanan dan berbagai topik lainnya. Pertanyaan dan jawaban dapat dilakukan secara spontan antara guru dan siswa, namun guru harus menyiapkan jawaban yang cerdas ketika siswa mengalami kesulitan dalam menjawab.

\section{Metode Mengingat (Memorization)}

Anak-anak sesungguhnya memiliki ingatan yang sangat baik. Mereka belum dihinggapi kelupaan sebagaimana halnya orang dewasa. Metode pengingat merupakan salah satu metode pembelajaran Veda. Guru mengucapkan, siswa mengulang sambil mengingat. Mahavakya atau penggalan mantra atau sloka terkenal sangat baik untuk diingat, seperti misalnya :

- Satyam Eva Jayati "Kebenaran Pasti akan menang"

- Tatvam Asi "aku dan kamu adalah Dia" (Chandogya Upanisad)

- prajñānam brahma "Brahman adalah kesadaran yang murni/kecerdasan tertinggi" (Aitareya Upanisad dalam Rgveda)

- Asato mā sad gamaya tamaso mā jyotīr gamaya mryormā 'mṛtam gamaya. "Bimbinglah saya dari kegelapan menuju cahaya yang terang, dari kematian menuju keabadian. "“

Dari 26 fokus kajian Brahma Widya, sejumlah kajian dapat diajarkan pada anak dengan pola penyederhanaan. Cerita dari Itihasa dan Purana yang sarat dengan nilai, kebajikan moral dan spiritualitas, seperti halnya cerita Dhruva dan Prahlada yang sangat terkenal. Pembacaan Kitab Suci Veda juga penting ditanamkan guna memupuk keimanan. Selain itu, juga teladan, nilai-nilai moralitas dan kesetiaan 
terhadap kebenaran yang ditunjukkan oleh Rama dan Pandawa dalam Itihasa patut untuk diajarkan sejak kecil (Aryadharma, 2011:217). Sesungguhnya tidak ada pembatasan usia dalam mempelajari Kitab Suci Veda, baik Veda Sruti maupun Smerti, namun pola pengajarannya harus disesuaikan dengan usia dan kebutuhan anak. Dalam sejarah peradaban Sanatana Dharma, sejumlah Rsi yang berusia muda, masih Kanak-Kanak diakui karena kemampuan spiritualitas dan pemahaman Veda yang sangat mapan. Demikian pula Sankaracarya yang dikenal jenius sejak usia dini mampu menguasai Veda pada usia anak-anak dan diakui secara luas. Di jaman ini, pengajaran Veda sesungguhnya harus diajarkan sejak usia dini guna membangun karakter mental, moralitas dan keimanan dari dalam diri. Sebab tantangan hidup sangat besar abad ini. Ajaran kebenaran, moralitas, kesetiaan, keberanian, kejujuran harus ditanamkan untuk selanjutnya diperkuat pada usia yang lebih matang.

Pola-pola pengajaran Veda yang sudah dilakukan sejak jaman lampau meliputi berbagai metode pembelajaran yang menyenangkan bagi anak. Namun sekaligus membangkitkan kecerdasan intelektual, emosional dan spiritual secara holistik. Dengan demikian, pengajaran Veda yang dilakukan pada anak usia dini tidak bertentangan dengan prinsipprinsip pendidikan anak usia dini, sesuai dengan keputusan Forum PUD 2007, diantaranya berorientasi pada kebutuhan anak, yakni berupaya optimalisasi semua aspek perkembangan baik perkembangan fisik maupun psikis, yaitu intelektual, bahasa, motorik, dan sosio dan emosional, belajar melalui bermain, menggunakan lingkungan yang kondusif, menggunakan pembelajaran terpadu maupun menggunakan media edukatif sebagai sumber belajar. Penggunaan media juga sangat penting, baik yang berupa audio visual yang digemari anak maupun alat peraga relevan. Selain itu, sejak jaman kuno, pembelajaran langsung melalui alam merupakan cara-cara yang sangat efektif, misalnya menjelaskan tentang Tuhan sebagai asal mula alam semesta. Demikian pula dalam pengajaran pentingnya menjaga lingkungan sebagai salah satu pengamalan Dharma, guru dapat mengajak siswa untuk melihat lingkungan dan betapa perilaku manusia tidak sangat menyakiti Ibu Pertiwi. Sehingga sejak dini, anak-anak telah memiliki kecintaan dan rasa hormat terhadap lingkungan sekitar. Namun demikian, keberhasilan pembelajaran ini bergantung pada kemampuan guru termasuk media yang digunakan.

\section{SIMPULAN}

Pengajaran Veda mestinya harus dilakukan sejak dalam kandungan Ibu. Sementara itu, pengajaran Veda sangat penting dilakukan pada anak usia dini. Berbagai metode dapat dilakukan seperti melalui Katha (cerita/Story Telling), Lagu, Kidung Pujian, Mantra sederhana, bermain peran, metode Tanya jawab dan kemampuan mengingat. Penanaman nilai-nilai mulia Veda semestinya sudah dilakukan sejak usia dini sehingga seorang anak mampu melewati masa remaja dengan penuh tantangan dan menjadi pribadi yang kuat pada usia dewasa. Pendidikan Hindu memandang pendidikan pada segala usia sama pentingnya, demikian pula pada pendidikan usia dini. Namun metode 
yang digunakan sedikit berbeda yang disesuaikan dengan kondisi psikologis manusia.

\section{DAFTAR PUSTAKA}

Aryadharma, Ni Kadek Surpi. 2011. Membedah Kasus Konversi Agama di Bali. Surabaya : Paramita.

Apte, D.G., 1949. Universities in Ancient India. Baroda : Faculty of Education and Psycology Maharaja Sarajirao University Of Baroda.

Bansi Pandit.2005. Pemikiran Hindu, Pokok-Pokok Pikiran Agama Hindu dan Filsafatnya. Terjemahan dari The Hindu Mind oleh IGA Dewi Paramita,S.S. Surabaya: Penerbit Paramita.

Bose, A.C., 2000. Panggilan Veda (The Call Of The Vedas). Penterjemah I Wayan Maswinara. Surabaya : Paramita.

Donder, I Ketut, 2007. Kosmologi Hindu Penciptaan, Pemeliharaan dan Peleburan serta Penciptaan Kembali Alam Semesta. Surabaya : Paramita

Debroy Bibek \& Dipavali Debroy. 2001. Brahmavaivarta Purana. Surabaya: Paramita

Debroy Bibek \& Dipavali Debroy. 2001. Bhavisya Purana. Surabaya : Paramita

Debroy Bibek \& Dipavali Debroy. 2001. Bhagavata Purana. Surabaya : Paramita

Debroy Bibek \& Dipavali Debroy. 2002. Kurma Purana. Surabaya: Paramita Debroy Bibek \& Dipavali Debroy. 2002. Varaha Purana. Surabaya: Paramita
Krishna, Anand. 2014. Bhagavad Gita. Jakarta : Pusat Studi Veda dan Dharma.

Machwe, Prabhakar. 2000. Konstribusi Hindu terhadap Ilmu Pengetahuan dan Peradaban. Denpasar : Widya Dharma.

Masitoh, dkk., 2005. Strategi Pembelajaran TK. Jakarya : Rinekacipta

Maharaja, Sripada Bhaktisvarupa Damodara, 2003. Bhagavata Sevarpanam A Glipse of the Relationship between a Discipline and the spiritual Master in the Tradition of Bhagavata Culture. Kolkata : University of Bhagavata Culture Press.

Mishra, P.S., 2008. Wejangan Guru Pujyasri Chandrasekharendra Saraswati Hindu Dharma Jalan Kehidupan Universal. Paramita : Surabaya.

Prabhupada, Sri Srimad A.C. Bhaktivedanta Svami,1994. Srimad Bhagavatam Skanda 1 jilid 1. Tim Penterjemah: Jakarta Pusat

Prabhupada, Sri Srimad

A.C.

Bhaktivedanta Svami,2009. Srimad Bhagavatam Skanda 4 jilid 1. Tim Penterjemah: Jakarta Pusat

Prabhupada, Sri Srimad A.C. Bhaktivedanta Svami, 1972. Bhagavad-gita Menurut Aslinya. ISKCON: Hanoman Sakti Di Bawah Lisensi The Bhaktivedanta Book Trust International,Inc

Saraswati, Sri Chandrasekharendra, 2009. Peta Jalan Veda. Judul Asli The Vedas. Penerjemah Hira Ghindwani dan Ni Putu Anggia Jenny. Jakarta : Media Hindu 
Sañkarācārya, 1983. Srimad Bhagavad Gita Bhasya. Translation by Dr. A.G Krishna Warrier. Madras : Sri Ramakrishna Math.

Sanjaya, Gede Oka. 2001. Visnu Purana. Surabaya : Paramita

Sharma, Arvin. 2000. Classical Hindu Thought : An Introduction. New York : Oxfort University Press.

Subramaniam, Kalama. 2006. Srimad Bhagavatam. Surabaya : Paramita. Sujiono, Yuliani Nurani., 2009. Konsep

Dasar Pendidikan Anak Usia Dini. Jakarta : Universitas Terbuka

Swami, Bhakti Vikasa. 2012. Brahmacari dalam Kesadaran Krsna. Denpasar: Yayasan Bhaktivedanta Indonesia.

Tim Penyusun, 2005. Pedoman Penyelenggaraan Pasraman. Surabaya: Paramitha.

Titib, I Made, 2004. Purana Sumber Ajaran Komprehensif. Surabaya : Paramita.

Titib, I Made. 2006. Veda, Sabda Suci Pedoman Praktis Kehidupan. Surabaya: Penerbit Paramita. 